SchwARZ, O. (1964): Quercus L., pp. 61-64 in Flora Europaea, vol. 1, edited by T. G. Tutin, V. H. HeYwood, N. A. Burges, D. H. Valentine, S. M. Walters and D. A. WeBB, Cambridge University Press, Cambridge.

Schwarzacher, T. and P. Heslop-Harrison (2000): Practical in situ Hybridization. Bios Scientific Publishers, Oxford.

ScogGan, S. J. (1978): The Flora of Canada, Part 3, Fagaceae. National Museum of Natural Sciences, Canada.

Siljak-Yakovlev, S., M. Cerbah, J. Coulaud, V. Stoian, S. C. Brown, V. Zoldos, S. Jelenic and D. PAPES (2002): Nuclear DNA content, base composition, heterochromatin and rDNA in Picea omorika and Picea abies. Theoretical and Applied Genetics 104: 505-512.

SoEPADMO, E. (1972): Fagaceae, pp. 265-388 in Flora Malesiana, series I, volume 7, edited by C. G. G. J. VAN STEENIS, Noordhoff International Publishing, Leyden.

Soltis, D. E. and P. S. Soltis (1999): Polyploidy: recurrent formation and genome evolution. Tree 14: 348-352.

Soltis, D. E., P. S. Soltis and J. A. TATE (2003): Advances in the study of polyploidy since Plant speciation. New Phytologist 161: 173-191.

StebBins, G. L. (1971): Chromosome Evolution in Higher Plants. Addison-Wesley Publishing Company, Massachusetts.
StreifF, R., T. LABbe, R. Bacilieri, H. Steinkellner, J. GLOSSL and A. KREMER (1998): Within-population genetic structure in Quercus robur L. and Quercus petraea (Matt.) Leibl. assessed with isozymes and microsatellites. Molecular Ecology 7: 317-328.

WANG, K.-S. (2003): Genetic diversity and temporal genetic structure in European beech (Fagus sylvatica L.). Silvae Genetica 52: 100-106.

WANG, L.-M. (1986): A taxonomic study of the deciduous oaks in China by means of cluster and karyotype analysis. Bulletin of Botanical Research 6: 55-69.

Zoldos, V., D. Papes, S. C. BRown, O. Panaud and S. SilJAK-YAKOVLEV (1998): Genome size and base composition of seven Quercus species: inter- and intra-population variation. Genome 41: 162-168.

Zoldos, V., D. Papes, M. Cerbah, O. Panaud, V. BesenDORFER and S. SILJAK-YAKOVLEV (1999): Molecular-cytogenetic studies of ribosomal genes and heterochromatin reveal conserved genome organization among 11 Quercus species. Theoretical and Applied Genetics 99: 969-977.

Zoldos, V., S. Siljak-Yakovlev, D. Papes, A. Sarr and O. PANAUD (2001): Representational difference analysis reveals genomic differences between $Q$. robur and Q. suber: implications for the study of genome evolution in the genus Quercus. Molecular Genetics and Genomics 265: 234-241.

\title{
Evaluation of Early Rooting Traits of Eastern Cottonwood That Are Important For Selection Tests
}

\author{
By B. Kovacevic ${ }^{1), *)}$, V. Guzina ${ }^{2)}$, M. Kraluevic-Balalic ${ }^{3)}$, M. Ivanovic ${ }^{4)}$ and E. Nikolić-Đorić(5)
}

(Received 30 th August 2006)

\begin{abstract}
Vegetative propagation of superior genotypes via stem cuttings depends on their development of strong vigorous root system. Fourteen characters of cutting rooting were examined in multiannual tests with 12 genotypes of eastern cottonwood (Populus deltoides BARTR. EX MARSH) in course of evaluation of their utilization in selection tests. Variability and relationship among examined characters, and cutting survival rate were

1) PhD, Institute for Lowland Forestry and Environment, Antona Cehova 13, 21000 Novi Sad, Serbia.

2) $\mathrm{PhD}$ (retired), Institute for Lowland Forestry and Environment, Antona Cehova 13, 21000 Novi Sad, Serbia.

3) $\mathrm{PhD}$, Faculty of Agriculture, Dositeja Obradovica 8, 21000 Novi Sad, Serbia.

4) $\mathrm{PhD}$, Institute for Field and Vegetable Crops, Maksima Gorkog 30, 21000 Novi Sad, Serbia.

5) MSc, Faculty of Agriculture, Dositeja Obradovica 8, 21000 Novi Sad, Serbia.

*) Communicating author: Branislav Kovacevic, Tel./Fax +38121-540385. E-mail: branek@uns.ns.ac.yu.
\end{abstract}

analyzed according to contribution of expected variances to the total variance and results of principal component analysis, stepwise regression analysis and path analysis. Along with total number and length of first-order roots, the characters that are regularly used in the assessment of rooting potential, our results signify dynamic shoot growth and uniform arrangement of roots on cutting at the beginning of growing period. The best results were obtained for shoot height at the second half of May. A rapid and non-destructive way of shoot characters' measurement allows testing of larger material and prevents losses in propagation material of interesting genotypes. Alone or together with total root number and length these alternative characters could be used for the improvement of selection tests and procedures for cultivar technology design.

Key words: Populus deltoides, cutting rooting characters, cutting survival rate, multivariate analysis.

\section{Introduction}

The hardwood cuttings of black poplars (section Aigeiros DUBY) are characterized by good rooting 
(SEKAWIN, 1969). This is due to pre-formed primordia in primary bark tissue, discovered in poplars by VAN DER LEK in 1924 (SMITH and WAREING, 1972). Primordia can also be initiated and activated on sites of recent wounding: on basal cut they form wound roots, and on upper cut adventitious shoots (SMITH and WAREING, 1972). Sufficient number and development of primordia (SмITH and WAREING, 1972; JAESTEDT, 1977) and their timely activation (OKORO and GRACE, 1976; PALlARDY and KozlowsKi, 1979; TSCHAPLINSKI and BlAKE, 1989; Rodenbaugh and PALLARDY, 1993) prevent imbalance in development of root system and shoot, which is able to cause stagnation of plants growth and even cuttings' decease.

The activation of primordia and cutting rooting is influenced by many factors. On one side are genetic sources of variation (MELCHIOR and HATTEMER, 1966; WILCOX and FARMER, 1968; YING and BAGLEY, 1979; GuZINA, 1987, HAN et al., 1994; KovACEVIC et al., 2005) and differences among cuttings within genotype, known as C - effect (SMith and WAREING, 1972; YING and BAGLEy, 1977; Li et al., 1998). There are also factors of the environment such as: soil texture (WILCOX and FARMER, 1968), temperature and precipitation (ZALESNY et al., 2005), microrelief (ALKINANI, 1972), storing conditions (NANDA and ANAND, 1970; FEGE, 1984) and nursery technology (FEGE, 1983).

The problems in cuttings' rooting that characterize the genotypes of eastern cottonwood (Populus deltoides BARTR. EX MARSH) particularly, could still compromise nursery production and the establishment of short rotation plantations for the production of biomass, as well. That is why modern poplar breeding programs regularly evaluate rooting ability of hardwood cuttings and its survival (Tessier DU CROss, 1984; GUZINA, 1987; HAN et al., 1994; ZALESNY et al., 2005).

The variability of the cutting rooting characters (mostly total number and length of first order roots) was examined in field conditions (YING and BAGLEY, 1977; KovACEviC et al., 2005), in controlled conditions in soil substrate (WILCOX and FARMER, 1968; YING and BAGLEY, 1977, GuZINA, 1987) and in water culture (MELCHIOR and HATTEMER, 1966). Relationship between rooting characters and survival rate is also important for evaluation of rooting characters (KOVACEVIC et al., 2005).

The aim of this work is to analyze the influence of genetic and environmental factors upon rooting and survival of stem cuttings in the first part of growing period. These results would serve to evaluate examined rooting characters for their future use in selection tests, but also in design of cultivar-adjusted nursery and plantation establishment technology.

\section{Material and Methods}

Twelve genotypes of eastern cottonwood (Populus deltoides BARTR. EX MARSH) were examined: PE19/66 and PE4/68 from Italy, and B-229, B-352, B-81, B-17, 124/81, 129/81, 54/76-28, S1-3, S6-7 and 182/81, from Institute for lowland forestry and environment, Novi Sad, Serbia. All of examined genotypes were selected from different full and half-sib families in order to obtain wider genetic diversity of examined group. However, they all origin from the breeding programs, so the shift towards better rooting and more narrow genetic variation then in original populations for examined traits could be expected. These clones were included in two separate studies:

- study of morphological characters of cutting rooting (Character study), and

- study of cutting survival rate (Survival study).

For these studies nursery experiments were established in the first half of April. The cuttings were made according to usual procedure: after rejecting the brittle top of stem long 150 to $220 \mathrm{~cm}, 20 \pm 2 \mathrm{~cm}$ long and more then $6 \mathrm{~mm}$ thick cuttings were made. The soil was treated by the insecticide (Lindane). Weeds were regularly treated by mechanical means. The precipitation for the period April-June in 1996 and 1998 was near average for the region (193 and $183 \mathrm{~mm}$, respectively) and in 1999 it was $235 \mathrm{~mm}$ ( $30 \%$ higher).

Nursery experiments for character study were established on humofluvisol (KovACEvIC et al., 2001), in three years (1996, 1998 and 1999), in four replications and by completely randomized design, in spacing $1,50 \times 0,10 \mathrm{~m}$. Five cuttings per plot were carefully taken from the soil and cleaned in four dates of observation during the first half of growing period: the beginning of May (the first date of observation), second half of May (second), the first half of June (third) and the middle of July (fourth). For each cutting with vital shoot the length of every first-order root and its distance from basal cut of cutting were measured, as well as height of dominant shoot (SH) and number of leaves on it (LN). The length of first-order roots was measured only in the first three terms. These measurements of root system were used for calculation of total number of roots (TRN) and total length of roots (TRL). Also, five following parts of the cutting were taken in consideration: basal cut (wound roots), basal part ( 0 to $5^{\text {th }} \mathrm{cm}$ from basal cut), middle part $\left(5^{\text {th }}\right.$ to $\left.10^{\text {th }} \mathrm{cm}\right)$, upper part $\left(>10^{\text {th }} \mathrm{cm}\right)$ and basal part with basal cut. For each specified part, following characters were derived: number of roots (RN0, RN5, RN510, RN1020 and RNB5, respectively) and their ratio to TRN (RN0P, RN5P, RN510P, RN1020P and RNB5P, respectively). Average plot values were used in further statistical analysis.

Nursery experiments for survival study were established in two years (1998 and 1999), on two sites, in spacing $1,50 \times 0,15 \mathrm{~m}$. Two sites for survival character examination differed in soil texture of surface horizon: loamy fluvisol and sandy fluvisol $(30 \%$ and $62 \%$ silt + clay content in surface horizon, respectively). Every combination of year $x$ site was treated as a treatment of source of variation called: "Environment". Environmental conditions varied from moderate year on sandy fluvisol to rainy year on loamy fluvisol. At the end of growing period cutting survival rate (SURV) was measured.

The variability of rooting and survival characters was examined by two-way ANOVA, random model:

$$
X_{i j m}=\mu+a_{i}+b_{j}+a b_{i j}+\varepsilon_{m(i j)} \text {, }
$$


where $X_{\mathrm{ijm}}$ stands for measured value, $\mu$ - average value, $a_{i}$ - effect of factor $A, b_{j}$ - effect of factor $B, a b_{i j}-$ effect of $\mathrm{A} \times \mathrm{B}$ interaction, and $\varepsilon_{\mathrm{mij}}$ - effect of uncontrolled variation. Samples were unequal because in some rare plots none of five observed cuttings had a vital shoot. Thus, the harmonic mean for mean number of repetitions (i.e. sample size) was calculated by formula:

$$
\tilde{\mathrm{n}}=\frac{\mathrm{p}^{*} \mathrm{q}}{\sum_{\mathrm{j}=1}^{\mathrm{q}} \sum_{\mathrm{i}=1}^{\mathrm{p}} 1 / \mathrm{n}_{\mathrm{ij}}}
$$

where $\mathrm{p}$ stands for number of treatments of the factor A, $q$ for number of treatments of factor $C$, while $n_{i j}$ stands for sample size (number of plots where non of dug up cuttings had a vital shoot) for $i^{\text {th }}$ treatment of first factor and $j^{\text {th }}$ treatment of second factor. Results of two-way ANOVA were used for calculation of expected variances for examined sources of variation:

$$
\begin{aligned}
& \text { for factor A: } \sigma_{A}^{2}=\frac{M S_{A}-M S_{A B}}{\tilde{n} q}, \\
& \text { for factor B: } \sigma_{B}^{2}=\frac{M S_{B}-M S_{A B}}{\tilde{n} p}, \\
& \text { for interaction A } \times \text { B: } \sigma_{A B}^{2}=\frac{M S_{A B}-M S_{E R R}}{\tilde{n}} \\
& \text { and for uncontrolled variation: } \sigma_{E R R}^{2}=M S_{E R R},
\end{aligned}
$$

where $\mathrm{MS}_{\mathrm{X}}$ stands for mean square of source of variation $X$ and $\sigma_{X}^{2}$ for expected variance of source of variation $\mathrm{X}$. Total expected variance was calculated as:

$$
\sigma_{T}^{2}=\sigma_{A}^{2}+\sigma_{B}^{2}+\sigma_{A B}^{2}+\sigma_{E R R}^{2}
$$

Contribution of expected variance for a source of variation $\mathrm{X}$ to the total variance calculated by formula:

$$
\frac{\sigma_{X}^{2}}{\sigma_{T}^{2}} * 100 \%,
$$

was used for evaluation of influence of source of variation X on variation of examined character (KIRK, 1968). In cases when genotype was source of variation, contribution of genotype expected variance to the total variance was considered as clonal repeatability or heritability in broad sense (BACKER, 1967). Characters describing ratio of number of roots from cutting's portions to TRN were transformed by arcsine - transformation $(\sqrt{X}$, where $X$ stands for the value in \%), while all characters describing number of roots were transformed by square transformation $(\sqrt{X+1})$ to meet normal distribution of frequencies that was required by most of used statistical methods. Negative expected variances were considered to be zero (ALLARD, 1960).

Spearman's rank correlation coefficient was used for examination of relationship between genotype ranks for characters of cutting rooting and cutting survival.

The principal component analysis was used to analyze grouping of examined rooting characters. Principal components were selected to meet criterion: $\lambda>1(\lambda$ stands for eigenvalue), and then rotated by Varimax method (KAISER, 1958; Thurstone, 1969). Examined characters were grouped in PC-groups according to principal component with which they had the highest factorial loading. Spearman's rank correlation coefficient between selected principal components and survival rate was used for evaluation of relationship between characters of analog PC-group and survival rate.

Stepwise regression analysis (SRA), forward method, was used in order to select characters that explained the most of variation of cutting survival. The variables were included in the model with cutting survival (SURV) as dependent variable, in course to achieve the fastest increase of the coefficient of determination. That increase was followed through F-statistics:

$$
\mathrm{F}=\frac{\Delta \mathrm{R}^{2}}{\left(1-\mathrm{R}^{2}\right) /(\mathrm{n}-\mathrm{k}-1)},
$$

where $R^{2}$ stands for coefficient of determination, $\Delta R^{2}$ for difference between model that included novel variable and the previous model, $\mathrm{n}$ stands for number of genotypes and $\mathrm{k}+1$ for number of variables included in model together with novel included variable. The degree of freedom for numerator is 1 , and for denominator (n-k-1) (DRAPER and SMITH, 1998; WonNACOTT and WonNACOTT, 1981). Significant F-test (for $\alpha_{0,05}$ ) was the criterion for a variable to be selected by stepwise regression analysis. Thus, it could be said that most of information on the influence of rooting characters on cutting survival rate was preserved, as the addition of any other characters did not significantly improved the model.

The direct and indirect effects on survival rate for rooting characters selected by stepwise regression analysis were calculated by path analysis. The direct effect was gained by the solution of the fundamental relation of the path analysis:

$$
z_{0}=p_{01} z_{1}+p_{02} z_{2}+\ldots+p_{0 k} z_{k}+p_{0 u} u
$$

where $z_{k}$ are the standardized regressors for $k^{\text {th }}$ independent variable, $\mathrm{u}$ - standardized residual, $\mathrm{z}_{0}$ - standardized reaction, and $p_{y k}$ standardized path coefficients, considered as the direct effect of the $\mathrm{k}^{\text {th }}$ character (DEWEY and LU, 1959; LI, 1975). Indirect effect of the independent variable $i$ through independent variable $j$ on the variation of dependent variable was considered significant if $\left|r_{i j} \cdot p_{y_{j}}\right|>p_{y_{j}}$, where $r_{i j}$ is coefficient of correlation of independent variables $i$ and $j$.

In statistical analysis the program package STATISTICA 7.1 was used (STATSOFT InC., 2006).

\section{Results}

According to contribution of expected variances to the total variance for rooting characters the influence of genotype decreased during the examined part of growing period (Tab. 1). Particularly high contribution of genotype variance (clonal repeatability) was in the first date of observation for RN510, RN5P and RB5P (> 45\%), while for total root number (TRN) and total root length (TRL) it was lower $(43 \%$ and $30 \%$, respectively). In other dates of observation considerable influence of genotype was for TRN, TRL, RN510 and RN1020. The influence of genotype on variation of number of leaves $(\mathrm{LN})$ increased till third date of observation, and then decreased, while for shoot height (SH) it 
Table 1. - Contribution of expected variances of examined sources of variation to the total variance for morphological characters of cutting rooting $(\%)$.

\begin{tabular}{|c|c|c|c|c|c|c|c|c|c|c|c|c|c|c|c|c|}
\hline \multirow{2}{*}{$\begin{array}{l}\text { Rooting } \\
\text { characters }^{1)}\end{array}$} & \multicolumn{4}{|c|}{$I^{\text {st }}$ date of observation } & \multicolumn{4}{|c|}{$2^{\text {nd }}$ date of observation } & \multicolumn{4}{|c|}{$3^{\text {rd }}$ date of observation } & \multicolumn{4}{|c|}{$4^{\text {th }}$ date of observation } \\
\hline & $G^{2)}$ & $\boldsymbol{Y}$ & $\boldsymbol{G} \times \boldsymbol{Y}$ & Err & $G$ & $\boldsymbol{Y}$ & $\boldsymbol{G} \times \boldsymbol{Y}$ & $E r \boldsymbol{r}$ & $G$ & $Y$ & $\boldsymbol{G} \times \boldsymbol{Y}$ & Err & $G$ & $Y$ & $\boldsymbol{G} \times \boldsymbol{Y}$ & Err \\
\hline$L N$ & $1,19^{3)}$ & $\underline{9,13}$ & $\underline{29,04}$ & 60,64 & 4,46 & $\underline{28,81}$ & 7,89 & 48,84 & 25,43 & $\underline{31,38}$ & $\underline{11,19}$ & 32,00 & 1,82 & $\underline{34,03}$ & 2,87 & 61,29 \\
\hline SH & $\underline{29,72}$ & 2,10 & $\underline{19,65}$ & 48,53 & $\underline{17,84}$ & $\underline{37,60}$ & $\underline{7,21}$ & 37,35 & $\underline{10,28}$ & 49,54 & $\underline{8.09}$ & 32,09 & 3,04 & $\underline{62,51}$ & 0,42 & 34,03 \\
\hline$T R L$ & $\underline{30,15}$ & 1,35 & 8,80 & 59,70 & 25,65 & 0,00 & $\underline{19,11}$ & 55,24 & $\underline{13,41}$ & $\underline{40,43}$ & $\underline{10,23}$ & 35,93 & - & - & - & - \\
\hline$R N 0$ & 0,00 & 0,00 & 0,65 & 99,35 & 0,00 & $\underline{32,56}$ & $\underline{10,55}$ & 56,88 & 2,99 & $\underline{74,97}$ & $\underline{5,02}$ & 17,03 & 0,96 & $\underline{83,40}$ & $\underline{2,25}$ & 13,39 \\
\hline$R N 5$ & 23,10 & 0,00 & 6,81 & 70,09 & $\underline{14,96}$ & $\underline{11,73}$ & 7,52 & 65,79 & 7,95 & $\underline{66,25}$ & 0,83 & 24,97 & $\underline{3,70}$ & $\underline{83,17}$ & 0,75 & 12,38 \\
\hline RNSIO & $\underline{53,82}$ & $\underline{7,48}$ & 0,00 & 38,71 & $\underline{32,46}$ & $\underline{4,65}$ & 5,65 & 57,24 & 25,09 & 14,38 & 3,27 & 57,26 & 21,24 & $\underline{8,82}$ & 0,00 & 69,94 \\
\hline$R N 1020$ & $\underline{26,26}$ & $\underline{10,05}$ & 29,70 & 33,99 & 30,24 & 1,01 & $\underline{10,41}$ & 58,35 & 26,51 & $\underline{10,97}$ & $\underline{17,41}$ & 45,11 & $\underline{16,65}$ & $\underline{13,22}$ & 9,59 & 60,54 \\
\hline$R B 5$ & 23,34 & 0,00 & 6,74 & 69,92 & $\underline{17,86}$ & 4,19 & 6,61 & 71,34 & 20,81 & $\underline{34,62}$ & 1,14 & 43,43 & 17,58 & $\underline{28,41}$ & 0,00 & 54,01 \\
\hline$T R N$ & 43,26 & $\underline{7,17}$ & $\underline{12,04}$ & 37,53 & $\underline{35,65}$ & 3,74 & $\underline{9,82}$ & 50,79 & 29,19 & $\underline{31,77}$ & $\underline{9.33}$ & 29,71 & 25,45 & $\underline{17,06}$ & 2,75 & 54,73 \\
\hline$R N O P$ & 0,00 & 0,00 & 0,00 & 100,00 & 0,00 & $\underline{39,28}$ & 1,69 & 59,04 & 1,11 & $\underline{80,86}$ & 0,00 & 18,03 & 0,00 & $\underline{85,77}$ & 1,03 & 13,19 \\
\hline$R N 5 P$ & $\underline{46,83}$ & 0,14 & 0,00 & 53,03 & $\underline{14,12}$ & 3,57 & 0,00 & 82,32 & 3,23 & $\underline{56,07}$ & 5,17 & 35,53 & 0,00 & $\underline{85,83}$ & $\underline{2,25}$ & 11,92 \\
\hline RN510P & 23,86 & 0,00 & $\underline{11,60}$ & 64,54 & $\underline{26,53}$ & 0,43 & 0,00 & 73,04 & 5,06 & 0,00 & 4,60 & 90,34 & 5,84 & $\underline{15,43}$ & 7,17 & 71,56 \\
\hline$R N 1020 P$ & $\underline{20,96}$ & 2,51 & 0,00 & 76,53 & $\underline{9,06}$ & 0,00 & 0,00 & 90,94 & $\underline{18,12}$ & 0,00 & 7,33 & 74,55 & 3,09 & $\underline{15,17}$ & 7,39 & 74,35 \\
\hline$R B 5 P$ & $\underline{46,43}$ & 0,13 & 0,00 & 53,44 & 24,33 & 1,37 & 0,00 & 74,30 & 10,44 & 0,00 & $\underline{14,01}$ & 75,55 & 4,16 & $\underline{24,41}$ & 2,56 & 68,87 \\
\hline
\end{tabular}

${ }^{1)}$ Abbreviations of rooting characters: LN - number of leaves; SH - shoot height (cm) TRL - total root length (cm); RN0 - number of roots on the basal cut; RN5 - number of roots on basal portion of cutting (0.-5. cm form basal cut); RN510 - number of roots on middle portion of cutting $(5 .-10 . \mathrm{cm})$; RN1020 - number of roots on upper portion of cutting (above 10. $\mathrm{cm}$ ); RNB5 = RN0 + RN5; TRN - total number of roots; RN0P $=$ RN0/TRN $* 100 \%$; RN5P $=$ RN5/TRN*100\%; RN510P $=$ RN510/TRN*100\%; $\mathrm{RN} 1020 \mathrm{P}=\mathrm{RN} 1020 / \mathrm{TRN} * 100 \% ; \mathrm{RNB} 5 \mathrm{P}=\mathrm{RNB} 5 / \mathrm{TRN} * 100 \%$.

2) Abbreviations of sources of variation: G - Genotype; Y - year; G x Y - interaction genotype x year; Err - error.

3) Significance of F-test: contributions of expected variances to the total variance are underlined if $\mathrm{p}$-values for F-test for analog source of variation was less then 0,05 .

Table 2. - Results of principal component analysis for grouping of examined rooting characters and relationship of selected principal components to cutting survival rate.

\begin{tabular}{|c|c|c|c|c|c|c|c|c|c|}
\hline \multirow{2}{*}{$\begin{array}{l}\text { Rooting }{ }^{1)} \\
\text { characters }\end{array}$} & \multicolumn{2}{|c|}{$1^{\text {st }}$ date of observation } & \multicolumn{2}{|c|}{$2^{\text {nd }}$ date of observation } & \multicolumn{2}{|c|}{$3^{\text {rd }}$ date of observation } & \multicolumn{3}{|c|}{$4^{\text {th }}$ date of observation } \\
\hline & PC 1 & PC 2 & PC 1 & PC 2 & PC 1 & PC 2 & PC 1 & PC 2 & PC 3 \\
\hline \multicolumn{10}{|c|}{ Factorial loadings } \\
\hline$L N$ & $\underline{0,673}$ & 0,460 & $\underline{0,643}$ & 0,535 & 0,360 & $\underline{0,797}$ & 0,180 & 0,141 & $\underline{0,867}$ \\
\hline SH & 0,331 & $\underline{0,826}$ & $\underline{0,759}$ & 0,372 & 0,184 & $\underline{0,906}$ & $-0,080$ & 0,265 & 0,907 \\
\hline$T R L$ & $\underline{0,710}$ & 0,637 & $\underline{0,809}$ & 0,498 & $\underline{0,674}$ & 0,581 & - & - & - \\
\hline RN5 & $\overline{0,330}$ & $\underline{0,913}$ & $\overline{0,936}$ & 0,202 & $\overline{0,358}$ & $\underline{0,854}$ & 0,068 & 0.952 & 0,256 \\
\hline RN510 & $\underline{0,682}$ & 0,623 & $\underline{0,687}$ & 0,658 & $\underline{0,740}$ & 0,556 & 0,597 & $\underline{0,659}$ & 0,381 \\
\hline RN1020 & $\underline{0,812}$ & 0,502 & $\overline{0,624}$ & 0,696 & 0,789 & 0,470 & 0,388 & 0,563 & $\underline{0,613}$ \\
\hline$R B 5$ & 0,328 & 0,913 & 0,951 & 0,208 & 0,416 & 0,839 & $-0,133$ & 0,938 & 0,063 \\
\hline$T R N$ & 0,689 & $\underline{0,707}$ & $\underline{0,817}$ & 0,526 & 0,631 & 0,717 & 0,155 & $\underline{0.925}$ & 0,320 \\
\hline$R N 5 P$ & $\underline{-0,931}$ & $-0,314$ & $-0,273$ & $\underline{-0,925}$ & $-0,843$ & $-0,232$ & $-0,554$ & 0,517 & 0,004 \\
\hline RN510P & $\underline{0.835}$ & 0,430 & 0,535 & $\underline{0,747}$ & $\underline{0,855}$ & 0,228 & $\underline{0,946}$ & 0,111 & 0,105 \\
\hline RN1020P & $\overline{0,830}$ & 0,266 & 0,219 & $\overline{0,892}$ & $\overline{0,770}$ & 0,444 & $\overline{0,381}$ & 0,171 & 0,753 \\
\hline$R B 5 P$ & $-0,932$ & $-0,313$ & $-0,345$ & $-0,911$ & $-0,894$ & $-0,320$ & $-0,772$ & 0,010 & $-0,593$ \\
\hline$\overline{\lambda^{3)}}$ & 6,002 & 4,560 & 5,481 & 4,990 & 5,322 & 4,676 & 2,536 & 3,792 & 3,198 \\
\hline$\lambda \Sigma \lambda_{i}$ & 0,500 & 0,380 & 0,457 & 0,416 & 0,443 & 0,390 & 0,231 & 0,345 & 0,291 \\
\hline$r_{S}^{4)}$ & 0,245 & $0,734^{* *}$ & $0,874 * *$ & 0,224 & 0,573 & 0,476 & 0,091 & 0,308 & $\overline{0,490}$ \\
\hline
\end{tabular}

1) Abbreviations for rooting characters are explained in Tab. 1 .

2) The highest loading of character is underlined.

3) $\lambda$ - the eigenvalue of principal component; $\lambda / \Sigma \lambda_{i}$ - ratio of variance of principal component and sum of variances of all principal components.

${ }^{4)} \mathrm{r}_{\mathrm{S}}$ - Spearman's rank correlation coefficient with survival rate. 
Table 3. - Results of ANOVA for cutting survival rate (SURV).

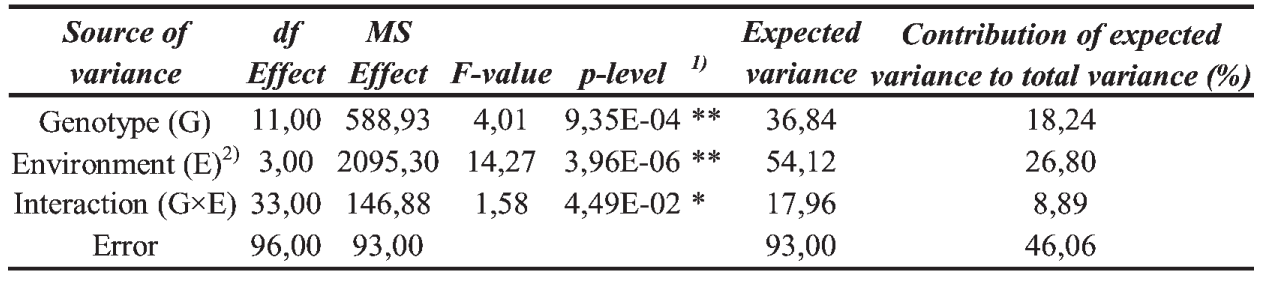

1) Significance of F-test: $*-p<0,05, * *-p<0,01$

2) Treatments of factor "Environment" were formed as combination of two examined years (moderate and rainy) and two forms of fluvisol on which nursery experiments for survival rate study had been established (sandy and loamy).

Table 4. - Spearman's rank coefficients of correlation between morphological characters of cutting rooting and survival rate.

\begin{tabular}{|c|c|c|c|c|}
\hline \multirow{2}{*}{$\begin{array}{l}\text { Rooting }{ }^{1)} \\
\text { character }\end{array}$} & \multicolumn{4}{|c|}{ Spearman's rank coefficients of correlation $\left(r_{S}\right)$} \\
\hline & $I^{\text {st }}$ date of obse & date of obs & date of obs & date of observation \\
\hline$L N$ & 0,441 & $0,776 * *$ & $0,853 * *$ & 0,510 \\
\hline$S H$ & $0,755 * *$ & $0,923 * *$ & $0,664 *$ & 0,538 \\
\hline$T R L$ & 0,524 & $0,727 * *$ & $0,713 * *$ & - \\
\hline RN5 & $0,776 * *$ & $0,797 * *$ & $0,587 *$ & 0,441 \\
\hline RN510 & $0,615 *$ & $0,636 *$ & $0,699 *$ & $0,601 *$ \\
\hline RN1020 & $0,636 *$ & $0,692 *$ & $0,615 *$ & 0,497 \\
\hline$R B 5$ & $0,776 * *$ & $0,825 * *$ & $0,622 *$ & 0,301 \\
\hline$T R N$ & $0,699 *$ & $0,748 * *$ & $0,685 *$ & $0,580^{*}$ \\
\hline$R N 5 P$ & $-0,510$ & $-0,434$ & $-0,517$ & 0,168 \\
\hline RN510P & $0,601 *$ & 0,448 & $0,720 * *$ & 0,189 \\
\hline$R N 1020 P$ & 0,399 & 0,559 & $0,622 *$ & 0,329 \\
\hline$R B 5 P$ & $-0,531$ & $-0,406$ & $-0,748 * *$ & $-0,217$ \\
\hline
\end{tabular}

1) Abbreviations for rooting characters are explained in Tab. 1.

decreased during the whole analyzed period. The influence of differences among genotypes on variation of characters that describe wound roots was of no significance. The influence of year increased during the period of observation, while the interaction genotype $x$ year was considerable for RN1020 and TRN, and in the first date of observation for shoot characters.

According to their highest loadings with selected principal components examined characters of cutting rooting were divided mostly in two groups (Tab. 2). Usually, in one group were characters describing number of roots on basal part of cutting (RN5 and RB5), as well as total number (TRN) and length of roots (TRL). In the other group were usually characters that describe contribution of examined parts of cutting to the total number of roots. Shoot characters (shoot height and number of leaves) were usually in the same group with RN5 and RB5, except the fourth date of observation, when they formed a separate group together with characters describing roots on upper part of cutting (RN1020 and $\mathrm{RN1020P}$ ). The number of roots on middle part of cutting had similar loadings with both of the first two principal components. Characters describing roots on basal cut (RN0 and RNOP) were not included in the analysis, as the influence of genotype on their variation was insignificant in every examined date of observation.

All examined sources of variation of cuttings' survival rate (SURV) achieved significant influence (Tab. 3). The most considerable contribution to the total variation, except the error, originated from differences among four environment treatments. The influence of genotype, as well as the influence of interaction genotype $x$ environment, was relatively weak but obvious.

Rank correlations $\left(\mathrm{r}_{\mathrm{S}}\right)$ between rooting characters and survival rate were considerable in the first three dates of observation, especially characters of third date (Tab. 4). Only TRN and RN510 had significant correlation with survival rate for all dates of observation. The highest correlations with survival rate had shoot height and number of roots on basal part with wound roots in second and number of leaves in third date of observation: $r_{\mathrm{S}}>0,80$.

Just one character, out of fourteen independent variables, was selected for each of four dates of observation by stepwise regression analysis: RN5 in the first (RN5 $5_{\mathrm{I}}$, $\mathrm{SH}$ in second $\left(\mathrm{SH}_{\mathrm{II}}\right), \mathrm{LN}$ in third $\left(\mathrm{LN}_{\mathrm{III}}\right)$ and $\mathrm{SH}$ in fourth date of observation $\left(\mathrm{SH}_{\mathrm{IV}}\right)$. Thus, shoot characters were selected for last three dates of observation. Selected characters were usually from the group with whose analog principal component RN5 and RB5 had the highest loadings, except for $\mathrm{SH}$ in fourth. The model based on character selected in second date of observation $\left(\mathrm{SH}_{\mathrm{II}}\right)$ had the highest coefficient of determination (adj. $\mathrm{R}^{2}=0,82$ ).

According to the results of path analysis for four selected rooting characters, shoot height in second date 
Table 5. - Stepwise (forward) regression analysis for relationship between morphological characters of cutting rooting and survival rate.

\begin{tabular}{|c|c|c|c|c|}
\hline 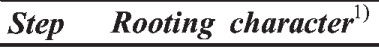 & $R^{2}$ & Adjusted $R^{2}$ & $F$ - to enter & p-level $^{2)}$ \\
\hline \multicolumn{5}{|l|}{$I^{\text {st }}$ date of observation } \\
\hline 1 RN51 & 0,643 & 0,607 & $17,997 * *$ & 0,002 \\
\hline \multicolumn{5}{|l|}{$2^{\text {nd }}$ date of observation } \\
\hline $1 \mathrm{SH} 2$ & 0,837 & 0,821 & $51,345^{* *}$ & 0,000 \\
\hline \multicolumn{5}{|l|}{$3^{\text {rd }}$ date of observation } \\
\hline $1 \mathrm{LN} 3$ & 0,794 & 0,774 & $38,604 * *$ & 0,000 \\
\hline \multicolumn{5}{|l|}{$4^{\text {th }}$ date of observation } \\
\hline $1 \mathrm{SH} 4$ & 0,615 & 0,577 & $15,989^{* *}$ & 0,003 \\
\hline
\end{tabular}

1) Abbreviations for rooting characters are explained in Tab. 1.

2) Significance of F-test for direct effects: $*-p<0,05, * *-p<0,01$.

Table 6. - Path coefficient analyses for relationship between selected rooting characters and cutting survival rate (SURV).

\begin{tabular}{l|c|cccc}
\hline Rooting character $^{1)}$ & Direct effect & \multicolumn{5}{|c}{ Indirect effect (characters in columns through characters in rows) } \\
\hline & & $\mathrm{RN} 5$ & $\mathrm{SH}_{\mathrm{II}}$ & $\mathrm{LN}_{\mathrm{III}}$ & $\mathrm{SH}_{\mathrm{IV}}$ \\
\hline $\mathrm{RN}_{\mathrm{I}}$ & $-0,11$ & $-0,11$ & $-0,09$ & $-0,09$ & $-0,08$ \\
$\mathrm{SH}_{\mathrm{II}}$ & $0,59^{*}$ & $0,48^{*}$ & 0,59 & $0,47^{*}$ & $0,38^{*}$ \\
$\mathrm{LN}_{\mathrm{III}}$ & 0,35 & $0,28^{*}$ & 0,28 & 0,35 & $0,27^{*}$ \\
$\mathrm{SH}_{\mathrm{IV}}$ & 0,21 & $0,15^{*}$ & 0,14 & 0,16 & 0,21 \\
\hline
\end{tabular}

Adjusted $\mathrm{R}^{2} \quad 0,895$

1) Abbreviations for rooting characters are explained in Tab. 2; label in suffix stands for date of observation.

2) Significance of F-test for direct effects: * $-\mathrm{p}<0,05, * *-\mathrm{p}<0,01$.

${ }^{3)}$ For indirect effect: * - the effect is significant as it is higher than direct effect of analyzed character.

of observation $\left(\mathrm{SH}_{\mathrm{II}}\right)$ had the highest direct effect on SURV (Tab. 6). Direct effects on of other selected characters were not statistically significant, but they achieved significant indirect effects on SURV through $\mathrm{SH}_{\mathrm{II}}$.

\section{Discussion}

Cutting rooting could be considered as a complex process, meaning not only formation of root system, but also the formation of rooted cutting in general. In that sense we examined both root and shoot characters as morphological characters of cutting rooting. These characters become important in early tests and in any other case when the establishment of proper nursery experiments for examination of survival rate is too difficult (limited quantity of propagation material, space for establishment of the experiments, available workers etc.). Also, efficient selection tests in field conditions are necessary when controlled conditions could not be provided for all genotypes of interest. YING and BAGLEY (1977) showed that field tests are acceptable for testing rooting in cuttings because there is strong correlation between results in controlled conditions in solid substrate and in field conditions $(r=0,85$ for total number of roots). In our trials we examined the possibility to improve selection tests by including some additional morphological characters regarding rooting on different parts of cutting and characters of shoot. Also, results of rooting potential trials could be of considerable interest in the establishment of nursery production as well as short rotation poplar plantations, considering the fact that cutting length in the establishment of SRIC plantations is usually just $30 \mathrm{~cm}$ (DE BELL and HARRINGTON, 1997).

Analysis of variation and relationship with survival rate provided us a basis for the discussion of suitability of examined rooting characters for the selection tests.

Generally, the variation of examined rooting characters and survival rate of cuttings was under strong influence of environment. That is in accordinance with the results of Kovacevic et al. (2004) and KovaceviC et al. (2005), additionally implying the necessity of multiannual nature of trials for the analysis of characters of cutting rooting in eastern cottonwood genotypes. Also, strong influence of error for some characters suggests the increase of size and number of plots in further trials.

Relatively weak influence of genotype to the variation of survival rate is in accordinance with weak contribution of additive variance to the total variation gained by COOPER and RANDALL (1973) for sixteen full-sib families of eastern cottonwood, and even weaker clonal repetition for 23 black poplar genotypes from trials of KovACEVIC et al. (2004). It is understandable because the survival rate is a complex character, affected by many characteristics of genotype and environment. Clonal average 
values for SURV varied from around $55 \%$ to even more then $80 \%$, which is a good result for Populus deltoides (data not shown)

Significant genotype $\mathrm{x}$ environment interaction for SURV (in accordinance with KovACEVIC et al., 2004), together with considerable effect of genotype $x$ year interaction on variation of some rooting characters suggests differences of examined genotypes in their reaction on environmental conditions. That reveals the basis for the adjustment of the technology of nursery and plantation establishment technology considering specific needs of genotype (HEILMAN et al., 1994; KovaCEVIC et al., 2004). Uniform and good rooting results for a genotype in different conditions allows less intensive nursery and plantation establishment and cultivation technology. On the other side, some hard-to-root genotypes could still be interesting (for superior biomass productivity for instance), but they would need more intensive care then easy-to-root genotypes. Thus, early information of rooting potential of interesting genotypes could improve and speed design of cultivar technology.

Methods of multivariate analysis that were used in these trials (principal component analysis, stepwise regression analysis and path analysis), allowed us to analyze relationship among rooting characters and between them and cutting survival rate. They helped us to achieve more comprehensive conclusions by reducing the complexity of multidimensional data. KHASA et al. (1995) used principal component analysis in survey of rooting of green cuttings in provenances of Racosperma sp. Also, Sing et al. (2004) concluded that principal component analysis could be used in breeding process for poplars and willows as a viable alternative to selection index. Sing and JHA (2004) used path coefficient analysis in studying the effect of many morphological characters on wood volume in eastern cottonwood.

Rooting characters were regularly examined in analysis of rooting processes or in evaluation of the cuttings' rooting potential for poplar genotypes. Main interest was in characters of root system, especially total root number and length (MELCHIOR and HATtemer, 1966; WILCOX and FARMER, 1968; YING and BAGLEY, 1977; GuZINA, 1987, Kovacevic et al., 2001; Kovacevic et al., 2005). The significant influence of genotype total root number (TRN) and length (TRL) of root for all dates of observation in our study was in accordinance with most of similar trials (MELCHIOR and HATTEMER, 1966; WILCOX and FARMER, 1968; YING and BAGLeY, 1977; SIEwECKI and GierThyCh in 1965 (according to TeIsser DU Cross, 1984); GuZINA, 1987, KovACEvic et al., 2005). Our results also emphasized strong relation of total number and length of roots with survival rate. These results confirm suitability of utilization of these characters (especially TRN) in selection tests.

However, results of our work suggest that some other analyzed rooting characters could also have an important role in evaluation of rooting ability of eastern cottonwood genotypes in selection tests.

The highest correlations with survival rate among alternative characters of root system achieved number of roots on basal part of cutting, with or without wound roots (RN5 and RB5, respectively). The exception was RN5 and RB5 in fourth date of observation. They were under considerable influence of genotype (especially RB5), which is in accordinance with results that got KovACEviC et al. (2005) for 23 genotypes of section Aigeiros. In all dates of observation they had the highest loadings (i.e. correlations) with principal component of their PCA-group. Their correlations with survival rate for the first two dates of observation (the beginning and second half of May) were stronger than for total number of roots. The character $\mathrm{RN} 5_{\mathrm{I}}$ was the only root character selected by stepwise regression analysis (SRA) for the first date of observation. It achieved significant indirect effect on SURV through $\mathrm{SH}_{\mathrm{II}}$. However, RN5 characters of the examined dates were always in the same group with analog TRN, which implies that considerable part of their variation is already explained by TRN.

Characters describing contribution of examined parts of cutting to the total number of roots had their highest loadings mostly with the opposite principal component then TRN had. That suggests that a part of their variation is not considerably correlated with variation of TRN and that they are bringing new information. However, Spearmans rank correlations with SURV for principal components with that they had the highest loadings were relatively low. Also, they were not selected by SRA in any date of observation. Differences among examined genotypes in these characters decreased during the spring. Their correlation with survival rate remained moderate until the third date of observation, when it appeared to be considerable. Later their correlation with survival rate diminished. Presented results, together with negative correlations with survival rate for RN5P and RB5P, stress the importance of root emergence on other parts of cutting then basal part. We assume that these characters could bring additional information in the assessment of rooting potential, beside information gained from total number of roots.

Number of roots on middle part of cutting (RN510) had high clonal repeatability and it had high correlations with cutting survival in all examined dates of observation, which is in accordance with KovACEVIC et al. (2001) and Kovacevic et al. (2005). However, like number of roots on upper part of cutting (RN1020), character RN510 was not selected by stepwise regression analysis in any date of observation. As its loadings with the first and second principal component were usually similar, it seems that RN510 combine the information of the variability of examined group of genotype gained from TRN and group of characters that describe root arrangement on cutting. However, it had similar dependence on variation among genotypes and similar correlations with SURV, as TRN had. Thus, this character could not be considered as a replacement of TRN. Even as an addition to TRN, this character would bring less additional information then characters of root arrangement. On the other side, results we gained for RN510 additionally emphasize the importance of root emergence on the middle part of cutting. That distinctive trait could be used in some rapid assessments.

Shoot characters: shoot height $(\mathrm{SH})$ and number of leaves (LN) were under significant but moderate influ- 
ence of genotype, which is in accordinance with results of KovacEvic et al. (2005). CoOPER and RANDALL (1973) found strong influence of genotype on shoot height of rooted cuttings at the end of growing period in Populus deltoides. WU et al. (1998) found one QTL that affected considerably shoot height of rooting cutting of Populus $x$ interamericana in nursery. However, it did not affect considerably shoot height in plantation after the first and fifth growing period. The results of principal component analysis suggest their strong relationship with total number of roots, which is in accordinance with the results of KOVACEVIC et al. (2001). Rank correlation coefficients emphasize considerable relationship of shoot characters with cutting survival. The shoot characters (mostly shoot height) were selected by stepwise regression analysis for last three dates of observation. The model with shoot height in second date of observation $\left(\mathrm{SH}_{\mathrm{II}}\right)$ had considerable coefficient of determination (adj. $R^{2}=0,82$ ), close to the coefficient of determination model for all four selected traits (adj. $\mathrm{R}^{2}=0,89$ ). When $\mathrm{LN}$ was excluded from the analysis for third date of observation, shoot height was the first and only included in the model, but with quite smaller coefficient of determination (adj. $R^{2}=0,77$ vs. adj. $R^{2}=0,61$, respectively). Also, regression models in that shoot height was the only independent variable, formed without intercept coefficient had coefficient of determination adj. $R^{2}>0,98$ for every examined date of observation (data not shown).

According to results of path analysis, direct effect on survival rate for $\mathrm{SH}_{\mathrm{II}}$ dominated over direct effects of other selected characters. However, significant indirect effect of $\mathrm{RN}_{\mathrm{I}}$ through $\mathrm{SH}_{\mathrm{II}}$ emphasizes the importance of early activation of primordial for subsequent shoot growth and cutting survival. We assume that shoot height growth, like cutting survival, could be regarded as a result of the plants ability to overcome problems caused by imbalance in development and growth of root system and shoot that occurs after the planting. That is in accordance with results of TSCHAPLINSKI and BLAKE (1989) and Rhodenbaugh and Pallardy (1993) who found significant positive correlation between early root production and subsequent increment of biomass of poplars rooted cuttings. Significant indirect effects on SURV through $\mathrm{SH}_{\mathrm{II}}$ that were found for $\mathrm{LN}_{\mathrm{III}}$ and $\mathrm{SH}_{\mathrm{IV}}$ stress the importance of early shoot growth dynamics for subsequent shoot growth. KovACEviC et al. (2005) even got that only shoot characters had significant correlations with survival rate in a year with unusually high precipitation in period April-June (more that $600 \mathrm{~mm}$ ). Thus, cuttings of genotypes that were able to achieve dynamic shoot growth in spring had more chances to survive.

Relatively moderate influence of genotype on the variation along with considerable positive relationship with cuttings' survival supports utilization of shoot characters in selection tests. Shoot characters (particularly shoot height) could be measured more efficiently then characters of root system, allowing more genotypes to be tested. Also, non-destructible way of measurement could prevent loss of rooted cuttings, which could be important when the propagation material of interesting genotypes is limited.
Naturally, it does not mean that shoot characters, as well as any other alternative rooting character, should replace total number or length of roots, or survival rate. But in cases (especially early tests) when the group of genotypes of interest is too big or quantity of propagation material per genotype too small to be evaluated through total number of roots or survival rate properly, the information gained from alternative rooting characters could be useful.

Correlations with cutting survival rate (SURV) were mostly considerable for rooting characters measured in second (second half of May) and third (the first half of June) date of observation. Regression models gained by stepwise regression analysis for these two dates of observation had the highest coefficients of determination (adj. $R^{2}=0,82$ and adj. $R^{2}=0,77$, respectively). Relatively high influence of genotype on the variation of characters in those two dates of observation additionally supports utilization of these two dates in further the selection tests. However, results of path analysis strongly supports shoot height in second date of observation $\left(\mathrm{SH}_{\mathrm{II}}\right)$, supporting the idea that second date of observation could be sufficient for assessment of rooting potential of genotypes of interest. On the other side, good results for characters of root emergence arrangement in third date of observation suggest that this date could provide some additional information on root system development.

The examination of cutting rooting is still an important task in the course of selection and utilization of clones of eastern cottonwood. Results of our work suggest that efficient analysis of relationship among examined characters, influence of differences among genotypes on their variation as well as their relationship to cutting survival, could be a relevant basis for complex evaluation of cutting rooting potential for genotypes of eastern cottonwood. Beside regularly used total number (TRN) and length of roots (TRL), our results emphasize the significance of shoot characters, characters describing rooting on basal and middle part of cutting and characters describing root emergence arrangement on cutting. There is a reason for all of them to be utilized in different assessments of rooting potential in eastern cottonwood genotypes. The significance of shoot characters is additionally supported by the possibility of efficient and non-destructible way of their measurement. Second half of May has the advantage to be proposed as selection time for observation in the middle Danube basin in breeding and cultivar utilization process. However, rooting characters measured at the first half of June could provide additional useful information.

\section{Acknowledgement}

This study was supported by the Ministry for Science and Environmental Protection of the Republic of Serbia. We are thankful to Dr. BERND DEGEN and two anonymous reviewers for their critical and constructive comments on previous version of this manuscript.

\section{References}

ALKINANI, A. (1972): [The influence of ecological factors of the Danube alluvium on the development of the rooted 
cuttings of Populus $x$ euramericana (DoDE) GUINIER cl. I-214.] PhD Thesis, University of Belgrade, Faculty of Forestry [in Serbian].

BECKER, W. A. (1967): Manual procedures in quantitative genetics. Second edition, Washington State University.

CoOper, D. T. and W. K. RANDALL (1973): Genetic differences in height growth and survival of cottonwood fullsib families. In: Proceedings of twelfth southern forest tree improvement conference: 206-212.

De Bell, D. S. and C. A. Harrington (1997): Productivity of Populus in monoclonal and polyclonal blocks at three spacings. Can. J. For. Res. 27: 978-985.

DEwEY, D. R. and K. H. LU (1959): A correlation and path analysis of components of crested wheatgrass seed production. Agron. J. 51: 515-518.

Draper, N. R. and H. SMith (1998): Applied Regression Analysis. Third edition. John Wiley \& Sons. INC.

FARMER, R. E. JR., M. Freitag and K. GARLiCK (1989): Genetic variance and "C" effects in balsam poplar rooting. Silvae Genetica 38: 62-65.

FEGE, A. S. (1983): The practice and physiological basis of collecting, storing and planting Populus hardwood cuttings. Gen. Tech. Report. NC-91.

FEge, A. S. and G. N. BRown (1984): Carbohydrate distribution in dormant populus shoot and hardwood cuttings. Forest Science 30: 999-1010.

Han, K. H., H. D. JR. Bradshaw, M. P. Gordon and K. H. HAN (1994): Adventitious root and shoot regeneration in vitro is under major gene control in an $\mathrm{F}_{2}$ family of hybrid poplar (Populus trichocarpa $x$ P. deltoides). Forest Genetics 1994, 1: 139-146.

Heilman P. E., G. EkuAng and D. B. Fogle (1994): First order root development from cuttings of Populus trichocarpa $x$ P. deltoides hybrids. Tree physiology 14: 911-920.

GuZINA, V. (1987): [The variability of poplar clones in their capacity of rooting of their cuttings]. Poplar, 151/152: 13-24. [in Serbian].

JESTAEDT, M. (1977): Einflusse auf die Wurzelentwicklung an Steckholzern von nordamerikanischen Schwarzpappelklonen. Die Holzzucht Juli 1977: 4-9.

KAISER, H. F. (1958): The varimax criterion for analytical rotation in factor analysis. Psychometrika 23, 187-200.

KHASA, P. D., G. Avallee and J. Bousquet (1995): Provenance variation in rooting ability of juvenile stem cuttings from Racosperma auriculiforme and $R$. mangium. Forest Science 41, 305-320.

KIRK, R. E. (1968): Experimental design procedures for the behavioral sciences. Wadsworth publishing company.

Kovacevic, B., V. Guzina and S. Orlovic (2001): Cuttings' rooting ability for clones of section Aigeiros. Third Balkan Conference "Study, conservation and utilization of the forest resources" Sofia. Conference Proc. Vol. II: $165-172$.

Kovacevic, B., M. Kraljevic-Balalic and M. Zoric (2004): Analysis of stability and adaptability of black poplar genotypes for cuttings' survival. XXXIV annual meeting of ESNA, Novi Sad. Proceedings. pp. 318-321.

Kovacevic, B., V. Guzina, P. Ivanis̆evic, S. Roncevic, S. ANDRAS̆EV and S. PEKEC (2005): Variability of cuttings' rooting characters and their relationship with cuttings' survival rate for poplars of section Aigeiros. Contemporary agriculture 54(1-2): 130-138.

LI, CH. CH. (1975): Path analysis - A primer. Pacific Grove, California.
LI, H. G., M. R. HuANG and D. M. CHEN (1998): Genetic variation and C-effects in rooting characters of Populus deltoides $x$ P. cathayana $\mathrm{F}_{1}$ clones. Nanjing Northeast Forestry University 26, 3: 12-15.

MARKOVIC, J. and S. RoNCEVIC (1986): Nursery production, pp. 133-152. In: Poplars and willows in Yugoslavia edited by Herpka, I., Marinkovic, P., Krstinic, A., Božic, J., VRataric, P. and Markovic, J. Poplar Research Institute, Novi Sad.

Melchior, G. H. and H. H. Hattemer (1966): Unterscheidung von Schwarzpappelklonen mit physiologishen Merkmalen. Silvae Genetica 15: 111-120.

NANDA, K. K. and V. K. ANAND (1970): Seasonal changes in auxin effects on rooting of stem cuttings of Populus nigra and its relationship with mobilization of starch. Physiologia Plantarum 23: 99-107.

OKoro, O. O. and J. GRACE (1976): The physiology of rooting Populus cuttings. I. Carbohydrates and Photosynthesis. Physiologia Plantarum 36: 133-138.

Pallardy, S. G. and T. T. Kozlowski (1979): Early root and shoot growth of Poplar clones. Silvae Genetica 28: 153-156.

Rhodenbaugh, E. J. and S. G. Pallardy (1993): Water stress, photosynthesis and early growth patterns of cuttings of three Populus clones. Tree physiology 13: $213-226$.

SEKAWIN, M. (1969): La propagation du peuplier. Second world consultation on forest tree breeding, Washington, 7-16 August 1969.: 22.

Singh, N. B., S. A. Huse and R. K. Gupta (2004): Principal component analysis of tree willow clones for genetic improvement of quantitative traits. Proceedings of $22^{\text {nd }}$ Session of International Poplar Commission, Santiago, Chile: 52.

SiNGH, N. B. and R. K. JHA (2004): Variability associations and path coefficient analysis in poplar (Populus deltoides BARTR.). Proceedings of $22^{\text {nd }}$ Session of International Poplar Commission, Santiago, Chile: 53.

SMith, N. G. and P. F. WAREING (1972): The distribution of latent root primordia in stems of Populus $x$ robusta and factors affecting the emergence of preformed roots from cuttings. Forestry 45: 197-209.

STATSoft INC. (2006): STATISTICA (data analysis software system), version 7.1.

TEISsiER DU CROS, E. (1984): Breeding strategies with poplars in Europe. Forest Ecology and Management 8: 23-39.

ThuRstone, L. L. (1969): Multiple-factor analysis. $8^{\text {th }}$ impression, The University of Chicago.

TsChaplinski, T. J. and T. J. Blake (1989): Correlation between early root production, carbohydrate metabolism and subsequent biomass production in hybrid poplar. Can. J. Bot. 67: 2168-2174.

WILCOX, R. J. and E. R. FARMER JR. (1968): Heritability and effects in early root growth of Eastern cottonwood cuttings. Heredity 23: 239-245.

WonnacotT, T. H. and R. J. WonnacotT (1981): Regression: a second course in statistics. John Wiley \& Sons.

YING, CH. CH. and W. T. BAGLEY (1977): Variation in rooting capability of Populus deltoides. Silvae Genetica 26: 204-207.

Zalesny, R. S., R. B. HAll, E. O. BAuer and D. E. ReimenSHNEIDER (2005): Soil temperature and precipitation affect the rooting ability of dormant hardwood cuttings of Populus. Silvae Genetica 54: 47-58. 